\title{
On acute gene expression changes after ventral root replantation
}

\section{Marten Risling ${ }^{*}$, Thomas Ochsmann ${ }^{1}$, Thomas Carlstedt ${ }^{2}$, Hans Lindå ${ }^{1}$, Stefan Plantman ${ }^{1}$, Elham Rostami ${ }^{1}$, Maria Angeria ${ }^{1}$ and Mattias K. Sköld ${ }^{1,3}$}

\author{
Department of Neuroscience, Karolinska Institutet, Stockholm, Sweden \\ 2 Department of Hand Surgery, Karolinska Institutet, Södersjukhuset, Stockholm, Sweden \\ ${ }^{3}$ Section of Neurosurgery, Uppsala University Hospital, Uppsala, Sweden
}

\section{Edited by:}

Jia Lu, DSO National Laboratories,

Singapore

Reviewed by:

Eng-Ang Ling, National University of

Singapore, Singapore

Bei-Ping He, National University of

Singapore, Singapore

${ }^{*}$ Correspondence:

Marten Risling, Experimental

Traumatology, Department of

Neuroscience, Karolinska Institutet,

Retzius väg 8, S-171 77 Stockholm,

Sweden.

e-mail: marten.risling@ki.se
Replantation of avulsed spinal ventral roots has been show to enable significant and useful regrowth of motor axons in both experimental animals and in human clinical cases, making up an interesting exception to the rule of unsuccessful neuronal regeneration in central nervous system. Compared to avulsion without repair, ventral root replantation seems to rescue lesioned motoneurons from death. In this study we have analyzed the acute response to ventral root avulsion and replantation in adult rats with gene arrays combined with cluster analysis of gene ontology search terms. The data show significant differences between rats subjected to ventral replantation compared to avulsion only. Even though number of genes related to cell death is similar in the two models after $24 \mathrm{~h}$, we observed a significantly larger number of genes related to neurite growth and development in the rats treated with ventral root replantation, possibly reflecting the neuroregenerative capacity in the replantation model. In addition, an acute inflammatory response was observed after avulsion, while effects on genes related to synaptic transmission were much more pronounced after replantation than after avulsion alone. These data indicate that the axonal regenerative response from replantation is initiated at an earlier stage than the possible differences in terms of neuron survival. We conclude that this type of analysis may facilitate the comparison of the acute response in two types of injury.

Keywords: ventral root, regeneration, inflammation, spinal cord, gene expression

\section{INTRODUCTION}

The pioneering studies of Ramon y Cajal demonstrated that injured neurons in the central nervous system (CNS) have a strong capacity to extend new axons into the peripheral nervous system (PNS; Cajal, 1928). This observation was reinvestigated by Aguayo and colleagues (Richardson et al., 1980; Aguayo et al., 1987). Cajal (1928) described that motor axons that had been severed due to spinal cord injury had the capacity to regrow to neighboring ventral roots. This observation was later confirmed with electron microscopy and intracellular labeling with horseradish peroxidase (Risling et al., 1983; Lindå et al., 1992). The regrowing axons penetrate through a highly unusual CNS environment which lacks a blood-brain barrier (BBB) function (Risling et al., 1989) but possesses a high content of cells bearing neurotrophin receptors (Frisen et al., 1992, 1998; Risling et al., 1992) and matrix molecules (Risling et al., 1993; Deckner et al., 2000). A clinical counterpart to this injury is a ventral root avulsion at the border between the CNS and PNS, typically caused by a high energy trauma such as a motorbike accident causing excessive trauma to the shoulder and head resulting in stretching and rupturing of ventral roots. Ventral root avulsion is not followed by spontaneous regrowth, since the avulsed roots are widely separated from the spinal cord inside the subarachnoid space or even pulled to a position outside the vertebral channel. Replantation of avulsed spinal ventral roots into the spinal cord has been shown to be enable significant and useful regrowth of motor axons in both experimental animals and in human clinical cases (Carlstedt et al., 1986, 1995, 2009; Cullheim et al., 1989, 1999).

The results from such treatment in humans are less successful in older patients and good reinnervation in distal muscles like in the hand is seldom possible. In a recent case report Carlstedt et al. (2009) described a preadolescent boy with complete brachial plexus avulsion injury that was treated by replantation of five ventral roots. Shoulder muscle recovery started $8-10$ months after the spinal cord operation. At 12-15 months, elbow function began to recover, followed 2 years postoperatively by forearm, wrist, and intrinsic hand muscle activity. This led to recovery of hand motor function without restoration of sensation. Bilateral motor cortex activity and activation of the sensory cortex on use of the affected hand was demonstrated by fMRI. The findings of that case study suggested that the restored hand function might rely on cortical sensory programs established before the injury (Carlstedt et al., 2009). Although the time needed for recovery seems very long, it cannot be excluded that the final result is dependent on several biological programs that are elicited in the early acute stage.

Previous studies indicate that ventral root replantation can be neuroprotective for motoneurons (Hoang and Havton, 2006; Eggers et al., 2010). If so, how rapidly after the avulsion should surgical intervention take place? In this study we have performed a gene array in the acute phase with subsequent cluster analysis 
to evaluate whether this type of analysis may be used to identify time points for critical events after ventral root avulsion and replantation.

\section{MATERIALS AND METHODS}

All animal experiments were approved by the local ethic's committee in Stockholm. Six adult Sprague-Dawley rats were anesthetized by Isoflurane inhalation and the lumbosacral spinal cord was exposed. The left L5 ventral root was identified and avulsed by gentle traction of the root. In three of the animals the root was replanted into the lateral funiculus (Figure 1). The wound was closed in layers. After $24 \mathrm{~h}$ the animals were euthanized with $0.5 \mathrm{ml}$ pentobarbital $(40 \mathrm{mg} / \mathrm{ml})$ and the inferior vena cava was cut open. The lumbosacral spinal cord was rapidly dissected out, meninges and rootlets removed. Thereafter the spinal cord segment L5 was immersed in RNAlater (Qiagen, Crawley, West Sussex, UK). Lumbar spinal cord specimens from three unoperated animals were collected and treated accordingly and used as controls. For microarray analysis, samples comprising the left ventral quadrant (lesion side) were used. RNA samples were analyzed at the Karolinska Institutet core facility for Bioinformatics and Expression Analysis ${ }^{1}$, where target preparation and hybridization to the microarray were completed. RNA was labeled with biotin to produce the final target according to Affymetrix standard procedures ${ }^{2}$. Labeled cRNA was then hybridized to the Affymetrix Rat Gene ST 1.0 array. Each of the 27,342 genes are represented on the array by approximately 26 probes spread across the full length of the gene. This 700,000 unique 25-mer oligonucleotide design is supposed to provide an accurate picture of gene expression. After probing and scanning, the quality of the images was checked. All arrays passed the Affymetrix quality control check. Following normalization, the change in gene expression between the three controls, the three avulsed, and the three avulsed and replanted rats was compared using an unpaired $t$-test and fold change values. Lists of genes that passed the selected significance level were uploaded to the Database for Annotation, Visualization, and Integrated Discovery (DAVID) ${ }^{3}$ for functional annotation and detection of enriched functional-related gene groups and enriched biological themes, particularly GO terms (Dennis et al., 2003; Huang da et al., 2009).

\section{RESULTS}

Thus, about 30,000 transcripts were analyzed in the three groups (replanted, avulsed only, and controls). The material was evaluated with regard to signal intensity and fold change (signal ratio in cross comparison tests). $p$-Values for the three intensity values for each gene in each group were calculated. Around 2000 genes in each comparison (replantation vs avulsion; replantation vs control; avulsion vs control) had a $p$-value of stronger than $<0.05$. The aim of the study was to perform a broad comparison of biological themes, based on a comparison of the about 2000 genes in each group that had a strong $p$-value. It would therefore be difficult to validate the findings by examination of individual genes. Instead, the lists of significantly regulated genes from each group were evaluated with

${ }^{1}$ www.bea.ki.se

${ }^{2}$ www.affymetrix.com

${ }^{3}$ http://david.abcc.ncifcrf.gov

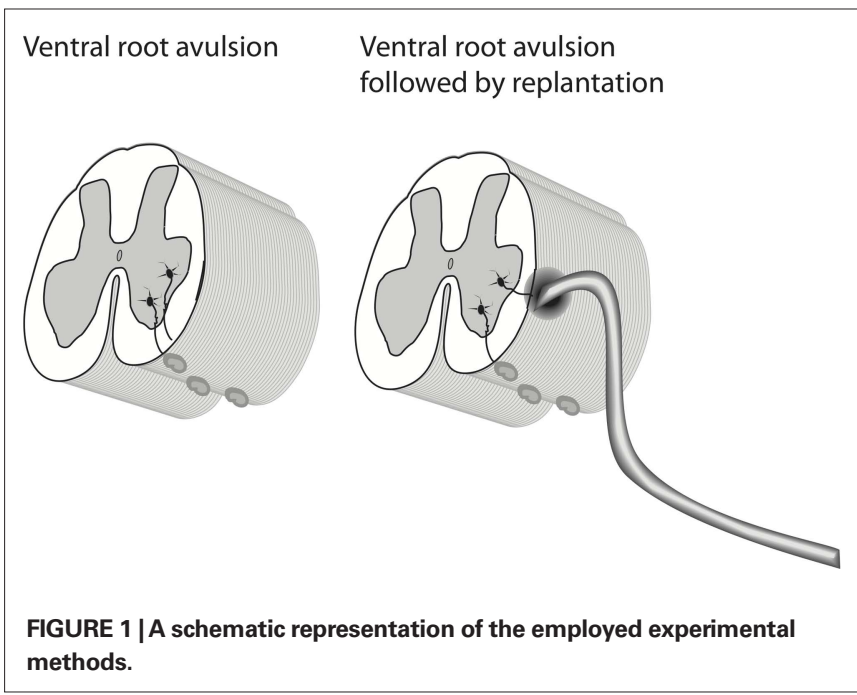

the aid of the DAVID. It was possible to group responding genes into functional-related gene groups ( $\mathrm{GO}$ - Gene Ontology search terms). All significantly regulated genes, both up- and down-regulated, were used in this part of the analysis in order to identify the most actively regulated GO families. Distinctive profiles for each of the examined conditions were apparent when the families of genes related to development, differentiation, inflammatory response, apoptosis, neurogenesis, and synaptic transmission were compared. For example, a number of genes related to neurogenesis were found to be up-regulated in animals subjected to avulsion combined with replantation (Figure 2). A distinct change in expression of genes related to synaptic transmission and conduction of nerve impulses was also observed in the replanted animals, but not after avulsion only. A response related to inflammation was more obvious after avulsion than replantation. No obvious difference with regard to cell death systems was found.

The differences were also assessed by cluster analysis of enriched biological themes, including pathways. The Enrichment score is based on the mean value of the-log of the $p$-values (EASEscore) for the members in that cluster. A cut-off value of 2.0 was used, which corresponds to a $p$-value $<0.01$. Thus, a higher Enrichment score value indicates a low $p$-value and therefore means that the cluster is significant. The most enriched clusters (most significantly regulated) observed after replantation were related to development and differentiation as well as synaptic transmission (Table 1). Avulsion injury only, induced large shifts in genes related to inflammation, signal transduction, and proliferation (Table 2). Enriched themes in a comparison between replantation and avulsion were development/differentiation and synaptic transmission (Table 3).

\section{DISCUSSION}

The biological changes initiated after a proximal motor axon lesion are very complex. Spinal motoneurons seem to have a stronger potential than average for axonal regrowth. However, the interaction between the motoneurons and the environment appears to be very complex. The outcome of untreated ventral root avulsion may be paralysis, loss of sensory function, and neurogenic pain. Clinical studies show that replantation with subsequent motor reinnervation can reduce neuropathic pain as well (Htut et al., 2006). 


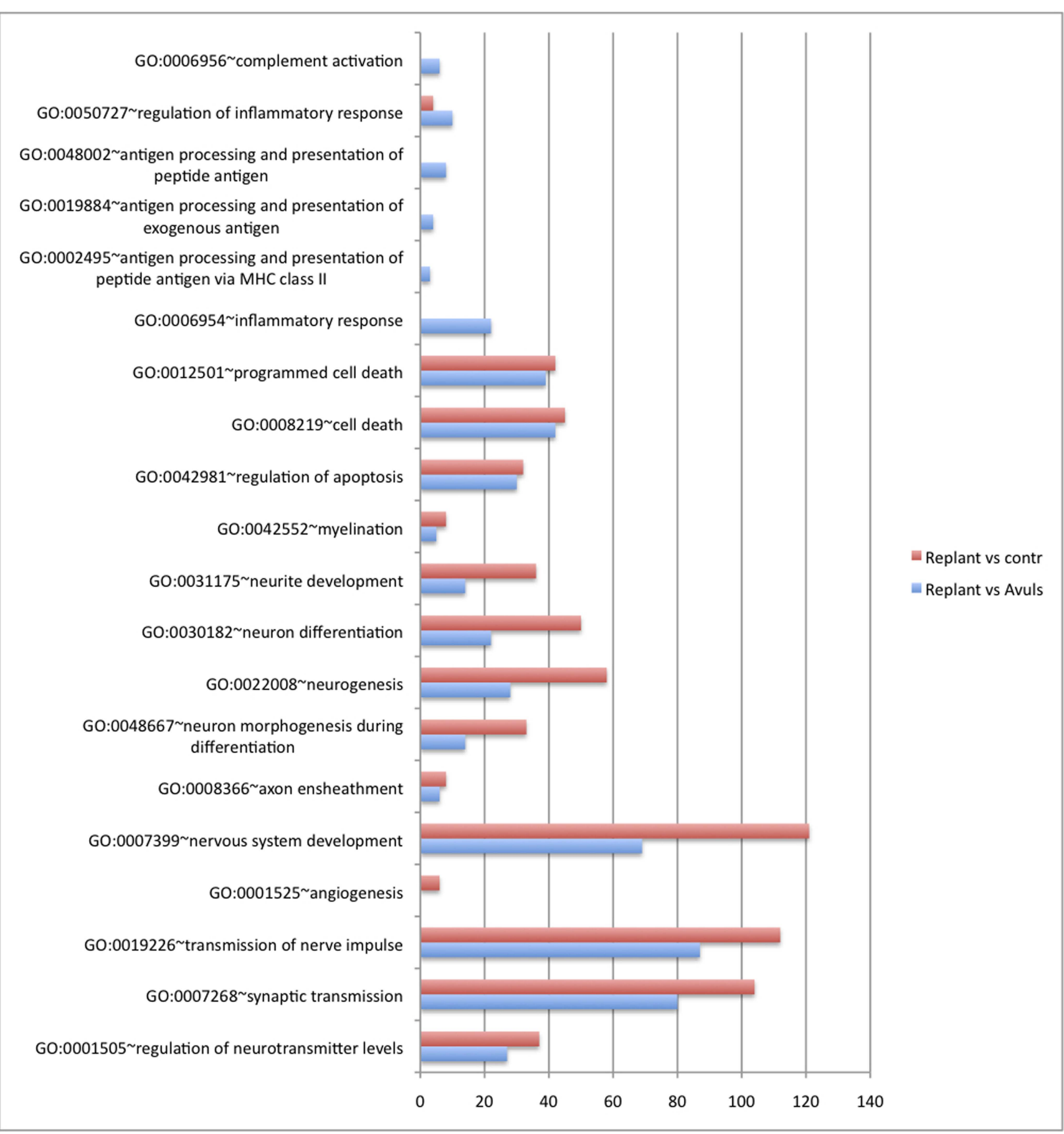

FIGURE 2 |A diagram illustrating the number of significantly regulated genes in selected categories after avulsion and avulsion plus replantation. The $x$-axis indicates the number of genes that have undergone significant changes in expression. Note that this number includes both up- and down- regulated genes. The number of cell death genes is similar in the two groups, while genes related to neurite development and neurogenesis show a much more prominent response after replantation than after avulsion only. The inflammatory response is more obvious after avulsion than after replantation.
The replantation will result in a limited but unavoidable spinal cord injury as well as disruption of the BBB (Sjögren et al., 1991). Many of the events (Risling et al., 1992, Frisen et al., 1998, Lindholm et al., 2001, 2002, 2004) that have been observed after lesions in the ventral funiculus can be assumed to occur also after this type of lesion. The replantation is performed to the lateral aspect of the spinal cord, a position more accessible for surgery than the ventral funiculus. It has been shown that regrowing axons are capable of finding a new route inside the spinal cord and navigate to the replanted root (Cullheim et al., 1989), while other axons use the pia 
Table 1 | Replantation vs control. Cluster analysis of regulated genes, employing the Database for Annotation, Visualization, and Integrated Discovery (DAVID). It was possible to group responding genes into functional-related gene groups ( $\mathrm{GO}$ - Gene Ontology search terms) and cluster analysis of enriched biological themes. The Enrichment score is based on the mean value of the -log of the $p$-values (EASEscore) for the members in that cluster. A cut-off value of 2.0 was used, which corresponds to a $p$-value $<0.01$. The most enriched cluster contains themes for neurite development and neuron differentiation.

\begin{tabular}{lcc}
\hline Term & Count & $\boldsymbol{p}$-Value \\
\hline FUNCTIONAL GROUP 1 ENRICHMENT SCORE: 8.67 & \\
GO:0007399 nervous system development & 121 & $1,20 \mathrm{E}-24$ \\
GO:0030182 neuron differentiation & 50 & $6,24 \mathrm{E}-11$ \\
GO:0048699 generation of neurons & 53 & $2,54 \mathrm{E}-10$ \\
GO:0031175 neurite development & 36 & $3,36 \mathrm{E}-09$ \\
GO:0048667 neuron morphogenesis & 33 & $4,35 \mathrm{E}-09$ \\
during differentiation & & \\
GO:0032990 cell part morphogenesis & 36 & $1,42 \mathrm{E}-06$ \\
GO:0048468 cell development & 104 & $1,73 \mathrm{E}-05$ \\
GO:0000902 cell morphogenesis & 47 & $3,63 \mathrm{E}-04$ \\
GO:0032989 $~$ cellular & 47 & $3,63 \mathrm{E}-04$ \\
structure morphogenesis & &
\end{tabular}

structure morphogenesis

\section{FUNCTIONAL GROUP 2 ENRICHMENT SCORE: 7.64}

GO:0007269 neurotransmitter secretion

GO:0045055 regulated secretory pathway

GO:0048489 synaptic vesicle transport

GO:0006887 exocytosis

GO:0003001 generation of a signal

involved in cell-cell signaling

GO:0045045 secretory pathway

GO:0032940 secretion by cell

GO:0016079 synaptic vesicle exocytosis

GO:0016192 vesicle-mediated transport

GO:0051649 establishment of

cellular localization

\section{FUNCTIONAL GROUP 3 ENRICHMENT SCORE: 5.79}

GO:0044255 cellular lipid

$62 \quad 1,75 \mathrm{E}-07$

metabolic process

GO:0008610 lipid biosynthetic process

GO:0006694 steroid biosynthetic process

GO:0016125 sterol metabolic process

GO:0008202 steroid metabolic process

FUNCTIONAL GROUP 4 ENRICHMENT SCORE: 3.68

GO:0048878 chemical homeostasis

GO:0006873 cellular ion homeostasis

GO:0019725 cellular homeostasis

FUNCTIONAL GROUP 5 ENRICHMENT SCORE: $\mathbf{3 . 1 9}$

GO:0046942 carboxylic acid transport

GO:0015849 organic acid transport

GO:0006865 amino acid transport

GO:0015837 amine transport

$\begin{array}{ll}37 & 3,74 \mathrm{E}-07 \\ 18 & 1,35 \mathrm{E}-06 \\ 18 & 1,98 \mathrm{E}-06 \\ 24 & 6,15 \mathrm{E}-05\end{array}$

\section{7}

30

3,37E-05

$1,50 \mathrm{E}-04$

$33 \quad 1,81 \mathrm{E}-03$

FUNCTIONAL GROUP 6 ENRICHMENT SCORE: 2.54

GO:0006631 fatty acid metabolic process

GO:0006633 fatty acid biosynthetic process

GO:0016053 organic acid biosynthetic process
1,35E-11

4,79E-10

2,31E-09

4,46E-08

$4,81 \mathrm{E}-07$

$6,48 \mathrm{E}-07$

$1,21 \mathrm{E}-04$

$3,80 \mathrm{E}-04$
$2,61 \mathrm{E}-12$

$1,72 \mathrm{E}-09$

18

2,35E-04

$18 \quad 2,63 \mathrm{E}-04$

$14 \quad 6,20 \mathrm{E}-04$

$14 \quad 4,56 \mathrm{E}-03$

24

10

1,43E-04

$10 \quad 7,74 \mathrm{E}-03$

$10 \quad 2,21 \mathrm{E}-02$
Table 2 |Avulsion vs control. A cluster analysis of the response to avulsion. Themes related to inflammatory response are enriched in this analysis.

Term Count $p$-Value

FUNCTIONAL GROUP 1 ENRICHMENT SCORE: 7.63

GO:0007166 cell surface receptor $172 \quad 8,11 \mathrm{E}-11$

linked signal transduction

GO:0050907 detection of chemical $\quad 94 \quad 3,71 \mathrm{E}-08$

stimulus during sensory perception

GO:0007600 sensory perception 102 4,19E-06

FUNCTIONAL GROUP 2 ENRICHMENT SCORE: 4.39

GO:0009617 response to bacterium

$15 \quad 6,72 \mathrm{E}-07$

GO:0032496 response to lipopolysaccharide

$2,70 \mathrm{E}-04$

GO:0002237 response to molecule

$6 \quad 3,80 \mathrm{E}-04$

of bacterial origin

FUNCTIONAL GROUP 3 ENRICHMENT SCORE: 4.15

GO:0042127 regulation of cell proliferation $44 \quad 7,94 \mathrm{E}-06$

GO:0048522 positive regulation of $\quad 64 \quad 1,89 \mathrm{E}-04$

cellular process

GO:0008284 positive regulation of $\quad 24 \quad 2,31 \mathrm{E}-04$

cell proliferation

FUNCTIONAL GROUP 4 ENRICHMENT SCORE: 3.99

GO:0002526 acute inflammatory response $\quad 19 \quad$ 2,41E-07

GO:0002443 leukocyte mediated immunity $\quad 14 \quad 4,06 \mathrm{E}-06$

GO:0002460 adaptive immune response based

on somatic recombination of immune receptors $\quad 13 \quad 9,91 \mathrm{E}-06$

built from immunoglobulin superfamily domains

GO:0002449 lymphocyte mediated immunity $12 \quad$ 2,87E-05

GO:0050776 regulation of immune response $\quad 15 \quad 9,76 \mathrm{E}-05$

GO:0002682 regulation of immune $\quad 15 \quad 1,64 \mathrm{E}-04$

system process

GO:0051240 positive regulation of multicellular $\quad 16 \quad 3,55 \mathrm{E}-04$

organismal process

GO:0006956 complement activation $\quad 10 \quad 3,71 \mathrm{E}-04$

GO:0050778 positive regulation of

$12 \quad 9,04 \mathrm{E}-04$

immune response

GO:0002684 positive regulation of $12 \quad 1,21 \mathrm{E}-03$

immune system process

$\begin{array}{lll}\text { GO:0002455 humoral immune response } & 6 & 1,49 \mathrm{E}-03\end{array}$

mediated by circulating immunoglobulin

GO:0006958 complement activation, $\quad 6 \quad 1,49 \mathrm{E}-03$

classical pathway

FUNCTIONAL GROUP 5 ENRICHMENT SCORE: 3.26

GO:0042127 regulation of cell proliferation

44 7,94E-06

GO:0008285 negative regulation of $23 \quad 2,39 \mathrm{E}-04$

cell proliferation

GO:0048523 negative regulation of $49 \quad 8,88 \mathrm{E}-02$

cellular process

FUNCTIONAL GROUP 6 ENRICHMENT SCORE: 2.55

GO:0048534 hemopoietic or lymphoid

$19 \quad 1,43 \mathrm{E}-03$

organ development

GO:0002520 immune system development $\quad 19 \quad 2,12 \mathrm{E}-03$

GO:0030097 hemopoiesis

$17 \quad 4,19 \mathrm{E}-03$

GO:0030099 myeloid cell differentiation

$5,12 \mathrm{E}-03$

(Continued) 
Table 2 | Continued

\begin{tabular}{lcc}
\hline Term & Count & $\boldsymbol{p}$-Value \\
\hline FUNCTIONAL GROUP 7 ENRICHMENT SCORE: $\mathbf{2 . 0 8}$ & \\
GO:0007067 mitosis & 15 & $2,73 \mathrm{E}-03$ \\
GO:0000087 $\sim$ M phase of mitotic cell cycle & 15 & $3,52 \mathrm{E}-03$ \\
GO:0022403 $\sim$ cell cycle phase & 21 & $8,20 \mathrm{E}-03$ \\
GO:0000279 $\sim$ M phase & 17 & $9,70 \mathrm{E}-03$ \\
GO:0000074 regulation of progression & 20 & $1,94 \mathrm{E}-02$ \\
through cell cycle & & \\
GO:0051726 $\sim$ regulation of cell cycle & 20 & $2,15 \mathrm{E}-02$ \\
\hline
\end{tabular}

mater as a conduit to enter the replanted root (Risling et al., 1991). It seems possible that the replanted ventral root, with its reactive Schwann cells, may have a trophic and neuroprotective effect on injured motoneurons. Previous studies indicate that ventral root replantation can be neuroprotective for motoneurons (Hoang and Havton, 2006; Eggers et al., 2010). Thus, replantation appears to elicit a number of important events in the spinal cord that may be partly beneficial with respect to regrowth to the replanted root. The acute changes in gene expression that were detected in the present study should therefore be assumed to be related to the initiation of a large number of biological changes that occur after this type of injury and surgery. Important themes that were affected were related to neurite growth, cell death, inflammation, and synaptic transmission.

Micro arrays have been employed to identify changes in gene expression after ventral root avulsion (Hu et al., 2002; Yang et al., 2006). The study by Hu et al. (2002) revealed increases in the expression of genes coding for proteins involved in the apoptosis cascades, as well as decreases in expression of genes related to energy metabolism, transporter proteins, ion channels, and receptors. It was also shown that cathepsins, metalloproteinases, and proteasome-related protein products were highly up-regulated in motor neurons following axotomy. The study by Yang et al. (2006) showed a decreased expression of genes that are known to facilitate neuronal survival and axonal regeneration.

Careful mapping of gene regions regulating neurodegeneration has revealed that the gene response linked to neurodegeneration after avulsion is closely related to $\mathrm{T}$ cell infiltration and major histocompatibility complex class II expression on microglia (Lidman et al., 2003; Olsson et al., 2005). The kinetics of the avulsion lesion has been summarized by Olsson et al. (2005): During the first few days following the injury, a first phase of microglial activation can be detected. After approximately 1 week the activated cells begin to express MHC class II. This is paralleled by a sparse lymphocyte infiltration and commencing death of axotomized cells. During the second and third post-operative weeks approximately $50-75 \%$ of the axotomized cells disappear.

These studies have generated important data relevant for understanding of how degeneration of motoneurons is initiated following avulsion injury. The present study, however, is to our knowledge the first direct comparison of the response to avulsion and replantation based on micro arrays with aid of cluster analysis. The results suggest that this type of gene ontology comparison can be a powerful and effective way to deal with the
Table 3 | Avulsion vs replantation. A cluster analysis of the response to avulsion compared to the response to replantation after avulsion. Themes relating to synaptic transmission are enriched.

\begin{tabular}{lll}
\hline Term & Count & $\boldsymbol{p}$-Value \\
\hline ENRICHMENT SCORE: 6.62 & 38 & $1,88 \mathrm{E}-10$ \\
GO:0031644 regulation of neurological & & \\
system process & 35 & $1,72 \mathrm{E}-09$ \\
GO:0051969 regulation of transmission of & & \\
nerve impulse & 43 & $2,09 \mathrm{E}-06$ \\
GO:0044057 regulation of system process & 79 & $4,82 \mathrm{E}-03$ \\
GO:0010646 regulation of & &
\end{tabular}

cell communication

\section{ENRICHMENT SCORE: $\mathbf{6 . 1 7}$}

GO:0006873 cellular ion homeostasis

GO:0019725 cellular homeostasis

GO:0048878 chemical homeostasis

$\begin{array}{ll}52 & 3,77 \mathrm{E}-08 \\ 56 & 7,93 \mathrm{E}-07 \\ 56 & 1,01 \mathrm{E}-05\end{array}$

\section{ENRICHMENT SCORE: $\mathbf{5 . 5 5}$}

GO:0006836 neurotransmitter transport

GO:0046903 secretion

GO:0007269 neurotransmitter secretion

GO:0003001 generation of a signal involved

$\begin{array}{ll}32 & 1,65 \mathrm{E}-14 \\ 41 & 1,23 \mathrm{E}-07 \\ 16 & 3,01 \mathrm{E}-07 \\ 21 & 6,62 \mathrm{E}-06\end{array}$

in cell-cell signaling

GO:0032940 secretion by cell

GO :0006887 exocytosis

GO:0048489 synaptic vesicle transport

GO:0016079 synaptic vesicle exocytosis

GO:0016192 vesicle-mediated transport

\section{ENRICHMENT SCORE: 3.96}

GO:0050905 neuromuscular process

GO:0008344 adult locomotory behavior

GO:0007628 adult walking behavior

$\begin{array}{rr}31 & 8,37 \mathrm{E}-06 \\ 21 & 2,31 \mathrm{E}-05 \\ 11 & 1,40 \mathrm{E}-04 \\ 8 & 5,76 \mathrm{E}-04 \\ 33 & 1,71 \mathrm{E}-01\end{array}$

\section{ENRICHMENT SCORE: $\mathbf{3 . 4 8}$}

GO:0051046 regulation of secretion

GO:0017157 regulation of exocytosis

GO:0051049 regulation of transport

GO:0060341 regulation of cellular localization

GO:0060627 regulation of

vesicle-mediated transport

GO:0051047 positive regulation of secretion

GO:0051050 positive regulation of transport

$\begin{array}{rr}15 & 2,12 \mathrm{E}-05 \\ 14 & 7,91 \mathrm{E}-05 \\ 8 & 7,47 \mathrm{E}-04 \\ 34 & 1,62 \mathrm{E}-05 \\ 12 & 2,14 \mathrm{E}-04 \\ 48 & 3,77 \mathrm{E}-04 \\ 33 & 4,03 \mathrm{E}-04 \\ 18 & 4,53 \mathrm{E}-04\end{array}$

\section{ENRICHMENT SCORE: $\mathbf{3 . 4 3}$}

GO:0034728 nucleosome organization

GO:0065004 protein-DNA complex assembly

GO:0006334 nucleosome assembly

GO:0034622 cellular macromolecular

complex assembly

GO:0006325 chromatin organization

\section{ENRICHMENT SCORE: 2.90}

\section{GO:0006865 amino acid transport}

GO:0015837 amine transport

GO:0046942 carboxylic acid transport

GO:0015849 organic acid transport

GO:0015804 neutral amino acid transport
$18 \quad 9,21 \mathrm{E}-04$

$27 \quad 2,11 \mathrm{E}-03$

\begin{tabular}{rr}
16 & $1,434 \mathrm{E}-05$ \\
16 & $2,063 \mathrm{E}-05$ \\
15 & $2,560 \mathrm{E}-05$ \\
25 & $1,072 \mathrm{E}-02$ \\
& \\
22 & $9,082 \mathrm{E}-02$ \\
\hline 16 & $2,082 \mathrm{E}-04$ \\
19 & $4,010 \mathrm{E}-04$ \\
20 & $1,491 \mathrm{E}-03$ \\
20 & $1,617 \mathrm{E}-03$ \\
7 & $2,709 \mathrm{E}-03$
\end{tabular}

(Continued) 
Table 3 | Continued

\begin{tabular}{lcc}
\hline Term & Count & $\boldsymbol{p}$-Value \\
\hline GO:0015807 L-amino acid transport & 7 & 7,361E-03 \\
ENRICHMENT SCORE: $\mathbf{2 . 4 0}$ & & \\
GO:0007612 learning & 14 & $3,83 \mathrm{E}-04$ \\
GO:0007613 memory & 11 & $2,21 \mathrm{E}-03$ \\
GO:0008542 visual learning & 8 & $2,29 \mathrm{E}-03$ \\
GO:0009416 response to light stimulus & 17 & $2,66 \mathrm{E}-03$ \\
GO:0045471 response to ethanol & 9 & $1,87 \mathrm{E}-01$
\end{tabular}

complex information that is generated by micro arrays. The data appears compatible with the notion that replantation initiates a significant growth response. The data of the present study show that the number of regulated genes related to neurite formation is much higher in the replanted animals, whereas the number of regulated cell death genes is similar in the two situations. Our data suggest that the inflammatory response is more prominent in animals subjected to avulsion without replantation. These data indicate that the axonal regenerative response from replantation is initiated at an earlier stage than possible differences in neuroprotective effects. Inflammatory changes that may precede degeneration seem be more pronounced already at $24 \mathrm{~h}$ in the animals subjected to avulsion only, although infiltration with $\mathrm{T}$ cells, other lymphocytes, and macrophages has not reached a maximum at this stage (cf. Olsson et al., 2005). Thus, this part of the inflammatory response may be dependent on resident cells, such as microglia. It should also be pointed out that a regulation

\section{REFERENCES}

Aguayo, A. J., Vidal-Sanz, M., VillegasPerez, M. P., and Bray, G. M. (1987). Growth and connectivity of axotomized retinal neurons in adult rats with optic nerves substituted by PNS grafts linking the eye and the midbrain. Ann. N. Y. Acad. Sci. 495, 1-9.

Cajal, S. R. y. (1928). Degeneration and Regeneration of the Nervous System. New York: Oxford University Press.

Carlstedt, T., Grane, P., Hallin, R. G., and Noren, G. (1995). Return of function after spinal cord implantation of avulsed spinal nerve roots. Lancet 346 , 1323-1325.

Carlstedt, T., Hultgren, T., Nyman, T., and Hansson, T. (2009). Cortical activity and hand function restoration in a patient after spinal cord surgery. Nat. Rev. Neurol. 5, 571-574.

Carlstedt, T., Linda, H., Cullheim, S., and Risling, M. (1986). Reinnervation of hind limb muscles after ventral root avulsion and implantation in the lumbar spinal cord of the adult rat. Acta Physiol. Scand. 128, 645-646.

Cullheim, S., Carlstedt, T., Linda, H., Risling, M., andUlfhake,B.(1989).Motoneurons reinnervate skeletal muscle after ventral root implantation into the spinal cord of the cat. Neuroscience 29, 725-733.
Cullheim, S., Carlstedt, T., and Risling, M. (1999). Axon regeneration of spinal motoneurons following a lesion at the cord-ventral root interface. Spinal Cord 37, 811-819.

Deckner, M., Lindholm, T., Cullheim, S., and Risling, M. (2000). Differential expression of tenascin- $\mathrm{C}$, tenascin- $\mathrm{R}$, tenascin/J1, and tenascin-X in spinal cord scar tissue and in the olfactory system. Exp. Neurol. 166, 350-362.

Dennis, G. Jr., Sherman, B. T., Hosack, D. A., Yang, J., Gao, W., Lane, H. C., and Lempicki, R. A. (2003). DAVID: database for annotation, visualization, and integrated discovery. Genome Biol. 4, P3.

Eggers, R., Tannemaat, M. R., Ehlert, E.M., and Verhaagen, J. (2010). A spatio-temporal analysis of motoneuron survival, axonal regeneration and neurotrophic factor expression after lumbar ventral root avulsion and implantation. Exp. Neurol. 223, 207-220.

Eroglu, C., and Barres, B. A. (2010). Regulation of synaptic connectivity by glia. Nature 468, 223-231.

Frisen, J., Risling, M., Korhonen, L., Zirrgiebel, U., Johansson, C. B., Cullheim, S., and Lindholm, D. (1998). Nerve growth factor induces process formation in meningeal

of genes for inflammatory molecules may relate to events that not are regarded as a component in the classical inflammatory response. For example the complement cascade molecule $\mathrm{Clq}$ has been shown to function as a molecular tag for synaptic removal. The molecular interactions that localize C1q specifically to weak synapses are unknown. However, microglia, the resident immune cells of the brain, produce large amounts of the receptors for $\mathrm{C} 1 \mathrm{q}$ and $\mathrm{C} 3$ and thus are likely to be responsible for the removal of unwanted synapses (Eroglu and Barres, 2010). It should not be excluded that similar mechanisms could be activated during the early stage following ventral root avulsion and could be involved in the removal of excitatory glutamate synapses (Lindå et al., 2000).

In a recent study we have observed differences between rotational and penetrating brain injuries with the same type of gene arrays and gene ontology analysis (Risling et al., 2010). Interestingly, the regenerative response that was observed in the present study after replantation could not be detected $24 \mathrm{~h}$ after a penetrating brain injury (Risling et al., 2010), further emphasizing the unique response following the replantation. It is concluded that this type of gene expression analysis can be of value for the examination of time points for critical events after neurotrauma and that the events after a superficial lesion in the spinal cord has some differences compared to a superficial lesion in the brain. We suggest that gene ontology can be a valuable tool that can be used to establish the time window for a delayed ventral root replantation, since the method seems capable to detect important differences between a regenerative and a nonregenerative response.

cells: implications for scar formation in the injured CNS. J. Neurosci. 18, 5714-5722.

Frisen, J., Verge, V.M., Cullheim, S., Persson, H., Fried, K., Middlemas, D. S., Hunter, T., Hokfelt, T., and Risling, M. (1992). Increased levels of trkB mRNA and trkB protein-like immunoreactivity in the injured rat and cat spinal cord. Proc. Natl. Acad. Sci. U.S.A. 89, 11282-11286.

Hoang, T. X., and Havton, L. A. (2006). A single re-implanted ventral root exerts neurotrophic effects over multiple spinal cord segments in the adult rat. Exp. Brain Res. 169, 208-217.

Htut, M., Misra, P., Anand, P., Birch, R., and Carlstedt, T. (2006). Pain phenomena and sensory recovery following brachial plexus avulsion injury and surgical repairs. J. Hand Surg. Br. 31, 596-605.

Hu, J., Fink, D., and Mata, M. (2002). Microarray analysis suggests the involvement of proteasomes, lysosomes, and matrix metalloproteinases in the response of motor neurons to root avulsion. Eur. J. Neurosci. 16, 1409-1416.

Huang da, W., Sherman, B. T., and Lempicki, R. A. (2009). Systematic and integrative analysis of large gene lists using DAVID bioinformatics resources. Nat. Protoc. 4, 44-57.

Lidman, O., Swanberg, M., Horvath, L., Broman, K. W., Olsson, T., and Piehl, F. (2003). Discrete gene loci regulate neurodegeneration, lymphocyte infiltration, and major histocompatibility complex class II expression in the CNS. J. Neurosci. 23, 9817-9823.

Lindå, H., Cullheim, S., and Risling, M. (1992). A light and electron microscopic study of intracellularly HRP-labeled lumbar motoneurons after intramedullary axotomy in the adult cat. J. Comp. Neurol. 318, 188-208.

Lindå, H., Shupliakov, O., Ornung, G., Ottersen, O. P., Storm-Mathisen, J., Risling, M., and Cullheim, S. (2000). Ultrastructural evidence for a preferential elimination of glutamate-immunoreactive synaptic terminals from spinal motoneurons after intramedullary axotomy. J. Comp. Neurol. 425, 10-23.

Lindholm, T., Cullheim, S., Carlstedt, T., and Risling, M. (2001). Expression of tenascin R and J1 mRNA in motoneurons after a traumatic lesion in the spinal cord. Neuroreport 12, 3513-3517. 
Lindholm, T., Cullheim, S., Deckner, M., Carlstedt, T., and Risling, M. (2002). Expression of neuregulin and ErbB3 and ErbB4 after a traumatic lesion in the ventral funiculus of the spinal cord and in the intact primary olfactory system. Exp. Brain Res. 142, 81-90.

Lindholm, T., Skold, M. K., Suneson, A., Carlstedt, T., Cullheim, S., and Risling, M. (2004). Semaphorin and neuropilin expression in motoneurons after intraspinal motoneuron axotomy. Neuroreport 15, 649-654.

Olsson, T., Piehl, F., Swanberg, M., and Lidman, O. (2005). Genetic dissection of neurodegeneration and CNS inflammation. J. Neurol. Sci. 233, 99-108.

Richardson, P. M., McGuinness, U. M., and Aguayo, A. J. (1980). Axons from CNS neurons regenerate into PNS grafts. Nature 284, 264-265.

Risling, M., Carlstedt, T., Lindå, H., and Cullheim, S. (1991). The pia mater-a conduit for regenerating axons after ventral root replantation. Restor. Neurol. Neurosci. 3, 157-160.

Risling, M., Cullheim, S., and Hildebrand, C. (1983). Reinnervation of the ventral root L7 from ventral horn neurons following intramedullary axotomy in adult cats. Brain Res. 280, 15-23.

Risling, M., Fried, K., Linda, H., Carlstedt, T., and Cullheim, S. (1993). Regrowth of motor axons following spinal cord lesions: distribution of laminin and collagen in the CNS scar tissue. Brain Res. Bull. 30, 405-414.

Risling, M., Fried, K., Lindå, H., Cullheim, S., and Meier, M. (1992). Changes in nerve growth factor receptor-like immunoreactivity in the spinal cord after ventral funiculus lesion in adult cats. J. Neurocytol. 21, 79-93.

Risling, M., Linda, H., Cullheim, S., and Franson, P. (1989). A persistent defect in the blood-brain barrier after ventral funiculus lesion in adult cats: implications for CNS regeneration? Brain Res. 494, 13-21.
Risling, M., Plantman, S., Angeria, M., Rostami, E., Bellander, B. M., Kirkegaard, M., Arborelius, U., and Davidsson, J. (2010). Mechanisms of blast induced brain injuries, experimental studies in rats. Neuroimage. doi: 10.1016/j.neuroimage.2010.05.031 [Epub ahead of print].

Sjögren, A. M., Thelestam, M., Blomqvist, L.,Linda, H., Remahl, S., and Risling, M. (1991). Extravasation of staphylococcal alpha-toxin in normal and injured CNS regions lacking blood-brain barrier function: observations after ventral root replantation. Brain Res. 559, 276-282.

Yang, Y., Xie, Y., Chai, H., Fan, M., Liu, S., Liu, H., Bruce, I., and Wu, W. (2006). Microarray analysis of gene expression patterns in adult spinal motoneurons after different types of axonal injuries. Brain Res. 1075, 1-12.

Conflict of Interest Statement: The authors declare that the research was conducted in the absence of any commercial or financial relationships that could be construed as a potential conflict of interest.

Received: 08 September 2010; accepted: 21 December 2010; published online: 04 January 2011.

Citation: Risling M, Ochsmann T, Carlstedt T, Lindå H, Plantman S, Rostami E, Angeria $M$ and Sköld MK (2011) On acute gene expression changes after ventral root replantation. Front. Neur. 1:159. doi: 10.3389/fneur.2010.00159

This article was submitted to Frontiers in Neurotrauma, a specialty of Frontiers in Neurology.

Copyright (c) 2011 Risling, Ochsmann, Carlstedt, Lindå, Plantman, Rostami, Angeria and Sköld. This is an open-access article subject to an exclusive license agreement between the authors and the Frontiers Research Foundation, which permits unrestricted use, distribution, and reproduction in any medium, provided the original authors and source are credited. 